\title{
THE IMPACT OF RELATIONSHIP QUALITY ON INCREASED ELECTRONIC COOPERATIVE RELATIONSHIPS
}

\author{
Ying-Pin Yeh \\ Yu Da University of Science and Technology \\ No. 168, Hsueh-fu Rd., Tanwen Village, Chaochiao Township, Miaoli \\ County, 361 Taiwan \\ kent88@ydu.edu.tw
}

\begin{abstract}
The increased electronic cooperative relationships of retailers and their opinions regarding focal firms are important factors in enhancing the value-added relationships between supplier and retailer. The principal purpose of this study is to organize and analyze the major factors affecting the electronic cooperative relationships between supplier and retailer. After reviewing the relevant literature, we integrate three constructs to identify factors affecting retailer willingness and apply an electronic exchange platform to increase cooperative relationships with their product suppliers. This study presents nine hypotheses based on data collected through a questionnaire survey of retailers in the Taiwanese automobile industry. This study uses a structural equation model to test the hypotheses using data from the respondents. Results show that relationship commitment is directly and positively related to increased electronic cooperative relationships, and increased electronic cooperative relationships are indirectly and positively related to trust, satisfaction, perceived service characteristics, coordination, and perceived adaptation.
\end{abstract}

Keywords: Relationship Quality, Perceived Service Characteristics, Coordination, Perceived Adaptation, Relationship Commitment

\section{INTRODUCTION}

The use of an electronic exchange platform to conduct business-to-business (B2B) electronic commerce is a powerful requirement in today's economy ${ }^{1}$. Electronic exchange platforms that employ information technology (IT) may be the most important technological breakthrough in B2B partnerships and are likely to radically alter the competitive landscape of industries ${ }^{2}$. To compete effectively in dynamic 
global markets, companies increasingly need to integrate their operations with those of their partners using an interorganizational system consisting of discrete functions within the supply chain. In many cases, this makes MRPII and JIT insufficient ${ }^{3}$. Because customer requirements can change rapidly, businesses must understand how to respond to customer requirements by changing their production schedules and supply plans. To make these changes, the business and its retailers must exchange the correct information in the right form at the right time so that both sides can integrate their inventory planning systems. However, the demand forecasting system currently used to drive supply chain activities must be re-evaluated. Forecasting adjustments can significantly alter production schedules. Many forecasters are unable to clearly explain how their forecast will affect the supply chain ${ }^{4}$. Most of the partners in the supply chain must decide what information to share with other partners and how to build a system that can effectively use this information.

Fulk and DeSanctis ${ }^{5}$ suggest that new technology generates changes in relations between organizations and in the organization itself. The new synonym-relationship technology recognizes the effect of technology on relationship quality. Establishing information and procedural standards is essential to improving the design and the adoption of such systems at an industry level, ultimately permitting these technologies to meet their intended spirit. At this point, further investigation is needed to explore the malleability of existing organizational processes and structures and whether they facilitate or impede the adaptation of new processes introduced through collaborative technologies. Both the buyer and the supplier must often make substantial adaptations and commitment of resources to develop partner-supplier relationships ${ }^{6}$. These efforts reflect the investment character of partnership establishment. The strategic nature of key supplier relationships makes it essential for the buyer to be able to evaluate the value creation potential of available suppliers.

This study investigates the effects of an electronic exchange platform in a relationship marketing context. This study focuses on how retailers use a combination of IT channels to interact with their product suppliers and how this interaction affects the quality of the relationship between the retailer and their product supplier. The most critical issues involve how the retailers work with the electronic exchange platform proposed by the automobile supplier and identifying what factors are involved. To facilitate the building of a sound electronic exchange platform, the automobile supplier must ensure that the retailer is willing to continue using this platform and will maintain a good cooperative relationship. Only then does the use of the electronic exchange platform result in improved business performance. This study attempts to (a) identify the types of electronic 
service characteristics that influential suppliers impose on their retailers; (b) explore the coordination between these electronic interactions and the supplier-retailer relationship; and (c) identify how influential suppliers and retailers adapt their own strategies in this electronic exchange environment.

The rational view adopted in this study is the basis for understanding how superior relationship quality can improve electronic cooperative relationships. We attempt to fill the gap in the literature regarding the roles that companies play in implementing electronic exchange platforms by comparing the approaches of suppliers and retailers toward the electronic exchange platform implementation designed to improve electronic interactions. This study contributes to an understanding of the link between electronic interactions and supplier-retailer relationships. The results of this study are particularly relevant to suppliers who transact or plan on transacting electronically with retailers in a B2B setting.

The remainder of this paper is organized as follows. Section 2 presents a summary of the pertinent literature. Section 3 presents the proposed modeling structure. Section 4 presents an analysis and discussion of the theoretical results. Section 5 presents a conclusion.

\section{LITERATURE REVIEW}

\subsection{Increased Electronic Cooperative Relationships}

An electronic exchange platform allows businesses to use information and Internet technology to conduct business with each other. The key is to integrate the operations between businesses - that is, businesses must use the Internet to coordinate their processes ${ }^{7}$. By virtualizing the chain connecting the manufacturer, the freight company, the distributor, and the retailer, the Internet and electronic data interchange can improve the flow of information. This in turn reduces system errors and makes the entire chain more efficient. An electronic exchange platform requires that all participating members coordinate their efforts and cooperate with each other. These participants may have complex business relationships, resulting in a number of social and political factors that influence electronic exchange platform planning 8 . The electronic exchange platform used in these supply chains can allow companies to reduce $\operatorname{costs}^{9}$, improve service and supply chain agility ${ }^{3}$, and increase customer satisfaction to achieve a competitive advantage ${ }^{9}$, among other performance improvements.

Cooperation involves the active participation of all actors toward sustaining the relationship ${ }^{10}$. In a downstream supply chain, the Internet enables transportation applications such as transportation scheduling and tracking of pick-ups and drop-offs at regional distribution centers as well as 
customer service applications such as receiving customer complaints and providing technical service ${ }^{11}$. It is important to understand industrial distribution based on the market before the development of the Web. When managers are concerned with the risk of customers leaving a relationship, they should focus on relationship quality. Trust is an important ingredient in stabilizing existing business relationships. Despite these challenges, manufacturers must develop trustworthy relationships to increase sales on the Internet and foster customer loyalty ${ }^{12}$. However, attaining the levels of trust necessary to make these interorganizational systems work is not an easy task, and the long-range outcomes are anything but certain ${ }^{7}$. Introducing an electronic exchange platform not only involves technical innovations but also considerable environmental and organizational changes, including changes in interorganizational relationships, the beliefs and attitudes of senior executives, managerial styles, and shared values. Joining an electronic exchange platform effort strengthens the relationships between supply chain companies ${ }^{13}$ and companies that have bargaining power over key suppliers. Collaboration and long-term relationships are also more probable in an electronic exchange platform ${ }^{14}$.

\subsection{Relationship Quality}

Relationship quality represents "the degree to which buyers are satisfied over time with the overall relationship as manifested in product quality, service quality, and price paid for value received and the degree to which the relationship functions as a partnership" 15 . This study focuses on "relationship quality" as a relationship outcome and an overall means of assessing the strength of a relationship between two firms. However, there is no clear consensus in the literature on the set of dimensions that comprise the construct of "relationship quality"16. Wulf et al. ${ }^{17}$ believe that relationship quality should include the dimensions of satisfaction, trust, and relationship commitment.

Walter et al. ${ }^{18}$ indicate that every supplier should be aware that a customer's perceived relationship quality is highest when both direct and indirect functions are fulfilled. For highly dependent customers, a supplier that fails to fulfill these functions becomes replaceable. It is even more important to improve the performance based on the customer's actual expectations and to spend resources adequately when the customer depends on the supplier. Ulaga and Eggert ${ }^{12}$ indicate that suppliers must understand how they can create and deliver value in B2B relationships. Huntley ${ }^{15}$ notes that technology-intensive product and service offerings may have idiosyncratic effects on relationship quality that are not evident in those relationships (e.g., between a retailer and its supplier). Athanasopoulou ${ }^{19}$ indicates that it is necessary to determine whether variables that affect the 
quality of other relationships have the same effect in an online environment and which new variables emerge. When the quality of the relationship improves, the parties no longer need coercive power and detailed contracts, because more flexible, harmonious, and friendly control mechanisms are sufficient $^{20}$.

\section{METHODS}

\subsection{Research Model and Hypotheses}

This study explores the increased electronic cooperative relationships between suppliers and retailers. Using the characteristics of the Taiwanese automobile industry electronic exchange platform and a review of the related literature, this study presents hypotheses based on research constructs such as relationship quality, perceived service characteristics, coordination, and perceived adaptation. Therefore, increased electronic cooperative relationships function as an endogenous variable in this study. Moreover, the electronic exchange platform in this study is a project for automobile suppliers; thus, retailers must be made aware of the goals and methods of the project in advance. The exogenous variables in this study are perceived service characteristics, coordination, and perceived adaptation. The automobile supplier and the retailer coordinate their efforts to acquire the trust and satisfaction of the retailer, resulting in a relationship commitment before the retailer increases electronic cooperation with the supplier. Therefore, the intervening variable is relationship quality (including trust, satisfaction, and relationship commitment).

Relationship commitment represents implicit or explicit continued investment between trading partners. It implies that the partners are willing to sacrifice short-term benefits to achieve long-term gains ${ }^{21}$. Anderson and Weitz $^{22}$ believe that relationship commitment indicates that partners intend to develop and maintain a long-term relationship. Moore ${ }^{23}$ finds that the relationship commitment of a company affects their continuity and long-term intentions to continue cooperation. The relationship commitment in an alliance demonstrates a long-term perspective, emphasizing a willingness to undertake further transactions in the future. Zeithaml et al. ${ }^{24}$ show that maintaining a good relationship increases a customer's positive behavior intentions and decreases negative behavior intentions. Good relationships help accelerate risk response processes, because a company's commitment to its partners drives continuous improvement in these processes ${ }^{25}$. This analysis leads to the following hypothesis:

H1. The relationship commitment that the retailer has in the electronic exchange platform is positively associated with increased electronic cooperative relationships. 
Morgan and $\mathrm{Hunt}^{26}$, who explored the relationships between businesses, show that higher relationship commitment and greater trust reduce a customer's propensity to leave. Anderson and Sullivan ${ }^{27}$ find that when a customer doing business with a company trusts that company and feels satisfied, the customer continues to interact with that business, and the two develop a close relationship that results in increased customer loyalty. Thus, if the customer is satisfied and trusts the business, this positively affects customer loyalty. Ganesan ${ }^{28}$ indicates that the supplier's trust in the buyer is directly correlated with a willingness to invest in and maintain a long-term cooperative relationship. Wilson ${ }^{29}$ shows that trust is the belief that the other party would act in the best interests of their party. Leonidou et al. ${ }^{30}$ indicates that trust is positively associated with commitment, which in turn is positively associated with satisfaction. Ulaga and Eggert ${ }^{12}$ find that satisfaction is positively associated with trust, and trust is positively associated with commitment. Wilson ${ }^{29}$ believes that the manufacturer's commitment to the supplier is the result of the supplier's investment in the relationship, with commitment being the outcome of a satisfactory transaction. This investment may include various experiments in the product or service. Apart from satisfaction, the level of investment made by each organization in relationship quality determines the commitment the manufacturer makes regarding their relationship. This analysis leads to the following hypotheses:

H2. The trust that the retailer has in the electronic exchange platform is positively associated with the retailer's relationship commitment.

H3. The satisfaction that the retailer feels in the electronic exchange platform is positively associated with the retailer's relationship commitment.

It is essential to know the service characteristics that drive customer value, and companies must know why people engage their services to develop appropriate service strategies ${ }^{31}$. Mackenzie ${ }^{32}$ believes that product performance and product quality are the basic conditions for a core product. Peripheral services, such as after-sales services, are mainly applicable to protection or product rectification. Therefore, the characteristics of the provided object reflect the characteristics of functionality (product) and immateriality (service). Selnes ${ }^{33}$ shows that when a product or service is not clearly defined, it is easier for the reputation of the company to affect customer loyalty. Web site design aspects, which are controlled by the retailer's marketing and internet/IT team, are antecedents to trust and commitment. Propensity to trust is important in economic transactions, because it reduces perceived risk ${ }^{34}$. This is particularly important for electronic exchange platforms, in which the buyer and seller are physically 
separated; contingencies are difficult to predict and incorporate into contracts; relationships are difficult to monitor; and cyber laws are not well defined. A high level of satisfaction with the services received in previous online transactions is likely to increase the propensity to trust ${ }^{35}$. Some researchers argue that the level of retailers' experience is related to their propensity to trust. Online retailers with a high propensity to trust perceive a lower risk and thus have more trust in online transactions ${ }^{36}$. This analysis leads to the following hypotheses:

H4. The perceived service characteristics of the retailer regarding the electronic exchange platform are positively associated with the retailer's trust in the supplier.

H5. The perceived service characteristics of the retailer regarding the electronic exchange platform are positively associated with the retailer's satisfaction with the supplier.

Coordination includes protocols, missions, and decision-making mechanisms designed to complete a goal shared by interdependent units. Examining just-in-time production relationships Frazier et al. ${ }^{37}$ find that a high level of coordination is closely linked to the realization of mutual expectations. Moh et al ${ }^{38}$ show that a sound coordinating mechanism must be established for the results from resources and effort. When organizations, controlled at a low level, adopt a mutually coordinating behavior as a practical strategy, this has a particularly beneficial effect on the output of these organizations. Heikkila ${ }^{39}$ highlights the importance of good relationships between a supplier and its key customers. Increasing coordination in the relationship enables both parties to improve their performance through a long-lasting high-quality relationship. Garcic-Dastugue and Lambert ${ }^{40}$ show that a lack of coordination yields an inefficient supply chain, including a stock buffer zone, underused capacity, outdated products, and decreased sales. Soliman and $\mathrm{Janz}^{41}$ show that with the advent of the Internet, trust remains a significant variable influencing the adoption and use of interorganizational systems. Other studies have confirmed these results, showing that organizations are more likely to engage in Internet-based exchanges with trusted parties ${ }^{42}$. This analysis leads to the following hypotheses:

H6. The coordination of the supplier with the retailers regarding the electronic exchange platform is positively associated with the trust of the retailers in the supplier.

H7. The coordination of the supplier with the retailers regarding the electronic exchange platform is positively associated with the satisfaction of the retailers with the supplier. 
Adaptation includes choosing system integrators based on requirements defined in earlier phase and installation ${ }^{43}$. Product suppliers provide not only hardware technology but also knowledge-based consultant services. Retailers usually hope to receive the supplier's long-term technical support and maintenance service, and there is a good chance that both the product supplier and the retailer will invest large amounts of time and money in this interactive relationship. Adaptation occurs when one party in a relationship alters its processes or the item exchanged to accommodate the other party ${ }^{44}$. Adaptation emphasizes that both parties accept the importance of establishing and maintaining long-term relationships, allowing the supplier to focus on satisfaction and trust rather than relationship commitment. Adaptations must be made to attitudes and values in addition to product capabilities or organizational practices. Therefore, product suppliers can build mutually valuable relationships with retailers through a trust-based collaboration process ${ }^{45}$. However, the manner in which trust is gained and its effect on e-business outcomes remain unclear ${ }^{46}$. Researchers from various disciplines have differing views on factors relating to trust in the electronic exchange platform and often define these factors in different ways. It is necessary to understand the concept of perceived adaptation and its consequences. Adaptation increases dependency. This implies that adapted supply chains themselves may be riskier. Adaptation has the potential to improve relationship quality, but this potential can be neutralized by mutual dependencies, tied up resources, and impaired flexibility ${ }^{1}$. This analysis leads to the following hypotheses:

H8. The perceived adaptation of the retailer in the electronic exchange platform is positively associated with the trust of the retailer with the supplier.

H9. The perceived adaptation of the retailer in the electronic exchange platform is positively associated with the satisfaction of the retailer with the supplier.

\subsection{Definition of Latent Variables}

This study reviews the definitions of latent variables in related research, and lists the operational definitions of the research dimensions in Table 1. 
Table 1. Operational definition of latent variables

\begin{tabular}{|c|c|c|}
\hline Latent Variables & Operational Definition & Reference \\
\hline $\begin{array}{l}\text { 1. Increased } \\
\text { electronic } \\
\text { cooperative } \\
\text { relationships }\end{array}$ & $\begin{array}{l}\text { The degree to which retailers feel that the } \\
\text { electronic exchange platform proposed by the } \\
\text { supplier has consistent policies and procedures } \\
\text { and the degree to which they feel it helps } \\
\text { increase their likelihood of cooperative } \\
\text { relationships. }\end{array}$ & $\begin{array}{l}{[1],[47],} \\
{[48]}\end{array}$ \\
\hline $\begin{array}{l}\text { 2. Relationship } \\
\text { commitment }\end{array}$ & $\begin{array}{l}\text { The degree to which retailers feel that they are } \\
\text { willing to invest in the electronic exchange } \\
\text { platform provided by the supplier and maintain } \\
\text { an alliance relationship with the supplier. }\end{array}$ & $\begin{array}{l}{[26],[48],} \\
{[49]}\end{array}$ \\
\hline 3. Trust & $\begin{array}{l}\text { The degree to which retailers feel that the } \\
\text { electronic exchange platform proposed by the } \\
\text { supplier has goodwill and competence. }\end{array}$ & {$[26],[48]$} \\
\hline 4. Satisfaction & $\begin{array}{l}\text { The degree to which retailers evaluate and } \\
\text { judge the electronic exchange platform } \\
\text { proposed by the supplier. }\end{array}$ & {$[33],[50]$} \\
\hline $\begin{array}{l}\text { 5. Perceived } \\
\text { service } \\
\text { characteristics }\end{array}$ & $\begin{array}{l}\text { The degree to which retailers know and feel the } \\
\text { core services, peripheral services, and } \\
\text { marketing elements of the electronic exchange } \\
\text { platform proposed by the supplier. }\end{array}$ & $\begin{array}{l}{[32],[51],} \\
{[52]}\end{array}$ \\
\hline 6. Coordination & $\begin{array}{l}\text { The degree to which retailers think that the } \\
\text { supplier is willing to fairly treat all retailers and } \\
\text { jointly resolve any problems that arise when } \\
\text { using the electronic exchange platform. }\end{array}$ & \\
\hline $\begin{array}{l}\text { 7. Perceived } \\
\text { adaptation }\end{array}$ & $\begin{array}{l}\text { When the supplier alters processes or the item } \\
\text { exchanged in the electronic exchange platform, } \\
\text { the degree to which the retailers think this will } \\
\text { accommodate the supplier in a relationship. }\end{array}$ & \\
\hline
\end{tabular}

\subsection{Measurement of Latent Variables}

This study also develops the required research variables and measurements. This study uses 21 manifest variables (Table 2) as multiple indicators for seven constructs (latent variables) in the research model. The question items used to measure the manifest variables in this research are mostly positive statements. The respondents indicated the amount they disagree or agree with the statements using a Likert 5-point scale categorized as strongly disagree, disagree, neutral, agree, and strongly agree. 
Table 2. Research variables and measurements

\begin{tabular}{|c|c|c|}
\hline \multirow{4}{*}{$\begin{array}{l}\text { Latent Variables } \\
\text { 1.Increased } \\
\text { electronic } \\
\text { cooperative } \\
\text { relationships }\end{array}$} & & \multirow{2}{*}{$\begin{array}{l}\text { Measurements } \\
\text { Willingness to continue to share information } \\
\text { through the automobile supplier's electronic } \\
\text { exchange platform. }\end{array}$} \\
\hline & V1 & \\
\hline & V2 & $\begin{array}{l}\text { Willingness to support marketing research } \\
\text { through the automobile supplier's electronic } \\
\text { exchange platform. }\end{array}$ \\
\hline & V3 & $\begin{array}{l}\text { Willingness to co-ordinate with the supplier to } \\
\text { test out new service items (such as a } \\
\text { customer complaint tracking platform) } \\
\text { through the electronic exchange platform. }\end{array}$ \\
\hline \multirow[t]{3}{*}{$\begin{array}{l}\text { 2.Relationship } \\
\text { commitment }\end{array}$} & V4 & $\begin{array}{l}\text { Willingness to do their utmost to integrate into } \\
\text { the supplier's electronic exchange platform. }\end{array}$ \\
\hline & V5 & $\begin{array}{l}\text { Top management fully support using the } \\
\text { supplier's electronic exchange platform to } \\
\text { fulfil all commitments to the customers } \\
\text { (including quality, delivery time, } \\
\text { specifications, etc.). }\end{array}$ \\
\hline & V6 & $\begin{array}{l}\text { Need to make a contract with the supplier to } \\
\text { manage the electronic exchange platform } \\
\text { cooperative relationship. }\end{array}$ \\
\hline \multirow[t]{3}{*}{ 3. Trust } & V7 & $\begin{array}{l}\text { Believing that the automobile supplier has the } \\
\text { professional capability for the electronic } \\
\text { exchange platform. }\end{array}$ \\
\hline & V8 & $\begin{array}{l}\text { Implementing the electronic exchange platform } \\
\text { with the automobile supplier has practical } \\
\text { benefits. }\end{array}$ \\
\hline & V9 & $\begin{array}{l}\text { The automobile supplier's electronic exchange } \\
\text { platform helps to increase efficiency in } \\
\text { purchasing and service. }\end{array}$ \\
\hline \multirow[t]{3}{*}{ 4. Satisfaction } & V10 & $\begin{array}{l}\text { Satisfied with the electronic exchange platform } \\
\text { cooperative relationship with the supplier. }\end{array}$ \\
\hline & V11 & $\begin{array}{l}\text { Continuing the electronic exchange platform } \\
\text { cooperative relationship with the supplier is } \\
\text { compatible with long-term interests. }\end{array}$ \\
\hline & V12 & $\begin{array}{l}\text { Continuing to invest in cooperative } \\
\text { relationship facilities promotes the } \\
\text { cooperative relationship with the supplier. }\end{array}$ \\
\hline
\end{tabular}


Table 2. Research variables and measurements (Cont.)

\begin{tabular}{|c|c|c|}
\hline Latent Variables & & Measurements \\
\hline \multirow[t]{3}{*}{$\begin{array}{l}\text { 5.Perceived } \\
\text { service } \\
\text { characteristics }\end{array}$} & V13 & $\begin{array}{l}\text { The core services (such as e-sales management } \\
\text { platform) provided by the electronic exchange } \\
\text { platform proposed by the supplier help } \\
\text { increase operational results. }\end{array}$ \\
\hline & V14 & $\begin{array}{l}\text { The peripheral services (such as e-customer } \\
\text { analysis and after sale e-service) provided by } \\
\text { the electronic exchange platform proposed by } \\
\text { the supplier help increase operational results. }\end{array}$ \\
\hline & V15 & $\begin{array}{l}\text { The marketing elements (such as advertisements } \\
\text { and promotion activities) of the electronic } \\
\text { exchange platform proposed by the supplier } \\
\text { help increase operational results. }\end{array}$ \\
\hline \multirow[t]{3}{*}{ 6. Coordination } & V16 & $\begin{array}{l}\text { The supplier treats your organisation and other } \\
\text { retailers fairly in its electronic exchange } \\
\text { platform cooperative relationships with the } \\
\text { retailers. }\end{array}$ \\
\hline & V17 & $\begin{array}{l}\text { The supplier is willing to jointly resolve } \\
\text { problems with your organisation when there is } \\
\text { a difference of opinions in the electronic } \\
\text { cooperative relationship. }\end{array}$ \\
\hline & V18 & $\begin{array}{l}\text { Need to set up a unit (personnel) or } \\
\text { co-ordination mechanisms to resolve conflicts } \\
\text { on the electronic exchange platform with the } \\
\text { supplier. }\end{array}$ \\
\hline \multirow[t]{3}{*}{$\begin{array}{l}\text { 7.Perceived } \\
\text { adaptation }\end{array}$} & V19 & $\begin{array}{l}\text { Developing a new service function requires } \\
\text { adjustment of procedures when unforeseen } \\
\text { disturbances arise in the working } \\
\text { relationships. }\end{array}$ \\
\hline & V20 & $\begin{array}{l}\text { Developing a new service function requires } \\
\text { structural changes in the organization to align } \\
\text { with the setup of these retailers }\end{array}$ \\
\hline & V21 & $\begin{array}{l}\text { Developing a new service function requires } \\
\text { flexibility in responding to demands put on } \\
\text { the working relationship by these retailers. }\end{array}$ \\
\hline
\end{tabular}

\subsection{Questionnaire Pretesting and Revising}

To facilitate understanding, the questionnaire employed positive statements and simple language as much as possible, avoiding the use of 
jargon, leading questions, and double-barreled questions. Relevant personnel from suppliers in the automobile industry discussed the preliminary questionnaire and recommended suitable retailers to discuss the questionnaire. Finally, we revised the questionnaire to make the wording simple and understandable. We tested the revised questionnaire on the retailers to determine whether they sufficiently understood the questions and revised them again based on the opinions of the respondents before carrying out a full-fledged survey.

\section{RESULTS}

\subsection{Reliability Analysis and Sample Structure}

The area of inquiry for this study is the Taiwanese automobile industry and its increased electronic cooperative relationships between suppliers and retailers. Taiwanese automobile industry retailers are the subject of this study; we seek to understand their opinions and attitudes toward the electronic exchange platform promoted by automobile suppliers. The subjects in this study include the retailers of the top five Taiwanese automobile suppliers.

We sent one questionnaire to every official Web site retailer in the Taiwanese automobile industry (a total of 1,230 retailers). This process yielded 316 returned questionnaires. After recording the returned questionnaires and removing incomplete responses, the actual number of valid questionnaires was 300 , for a return rate of $24.4 \%$. Analyzing the number of employees and annual turnover of the sample companies indicates that most respondents are from small- and medium-sized enterprises. Thus, the samples are highly representative of the automobile industry in Taiwan. These sample firms placed all orders electronically.

To investigate the possibility of non-response bias in the data, we performed a test for statistically significant differences in the response of early and late waves of returned surveys ${ }^{55,56}$. For each phase, we treated the last wave of surveys received as representative of non-respondents. We split each survey sample into two groups based on early and late survey return times and performed t tests on the responses of both groups. The t tests yielded no statistically significant differences among the survey items tested. These results suggest that non-response bias does not significantly affect this study.

Table 3 shows the data reliability using Cronbach's $\alpha$. All constructs (latent variables) for the increased electronic cooperative relationships between supplier and retailer had high reliability, with Cronbach's $\alpha$ exceeding 0.8. Data reliability is generally acceptable. 
Table 3. Results of reliability analysis

\begin{tabular}{ll}
\hline Latent variables & Cronbach's $\alpha$ \\
\hline Increased electronic cooperative relationships & 0.875 \\
Relationship commitment & 0.851 \\
Trust & 0.873 \\
Satisfaction & 0.886 \\
Perceived service characteristics & 0.845 \\
Coordination & 0.823 \\
Perceived adaptation & 0.861 \\
\hline
\end{tabular}

\subsection{Confirmatory Factor Analysis}

Each indicator variable in the measurement model should load only one factor; that is, none of the indicators are complex variables (measuring multiple latent variables) ${ }^{57}$. We used confirmatory factor analysis (CFA) to assess the psychometric properties of the measures used in this study and removed two complex variables (Items 11 and 15). The model fit also used the estimates of CFI, GFI, AGFI, NFI, NNFI, and RMR (Table 4). The results in Table 4 indicate a good fit with the data; when the fit indices exceeded or approached 0.9, the estimated RMR was 0.0284, and the AGFI exceeded 0.8 .

Table 4. Summary of measurement statistics

\begin{tabular}{cc}
\hline & Modified Model \\
\hline$\chi^{2}$ & 396.6295 \\
$\mathrm{df}$ & 181 \\
$\chi^{2} / \mathrm{df}$ & 2.191 \\
GFI & 0.8932 \\
AGFI & 0.8507 \\
RMR & 0.0284 \\
NFI & 0.9179 \\
NNFI & 0.9402 \\
CFI & 0.9531 \\
\hline
\end{tabular}

Notes: Sample Size $=300$; GFI= goodness of fit index; AGFI= GFI adjusted for degrees of freedom; RMR=root mean square residual; NFI= normed-fit index; $\mathrm{NNFI}=$ non-normed-fit index $; \mathrm{CFI}=$ Bentler's comparative fit index .

We assessed the reliability of the measures using composite reliability and variance extracted estimates. The composite reliability of each construct exceeded 0.7 in this study, satisfying a minimally acceptable level ${ }^{57}$. This 
research shows the assessed validity using the $t$ values of the factor loadings. All indicator $t$ values ranged from 12.4797 to 19.4911, indicating that all factor loadings were significant $(\mathrm{p}<.001)$. These results support the convergent validity of all indicators that effectively measured the same construct $^{58}$.

\subsection{Path Analysis}

Based on these results, we used SEM to perform theoretical model testing with path analysis. The CFI, GFI, NFI, and NNFI exceeded or were close to 0.9; the estimated RMR was 0.0291; and the AGFI exceeded 0.8. The research model achieved a relatively good $\mathrm{fit}^{59}$. Figure 1 shows a summary of the path analysis results. Almost all path coefficients in the current model were statistically significant, as hypothesized, except for H8.

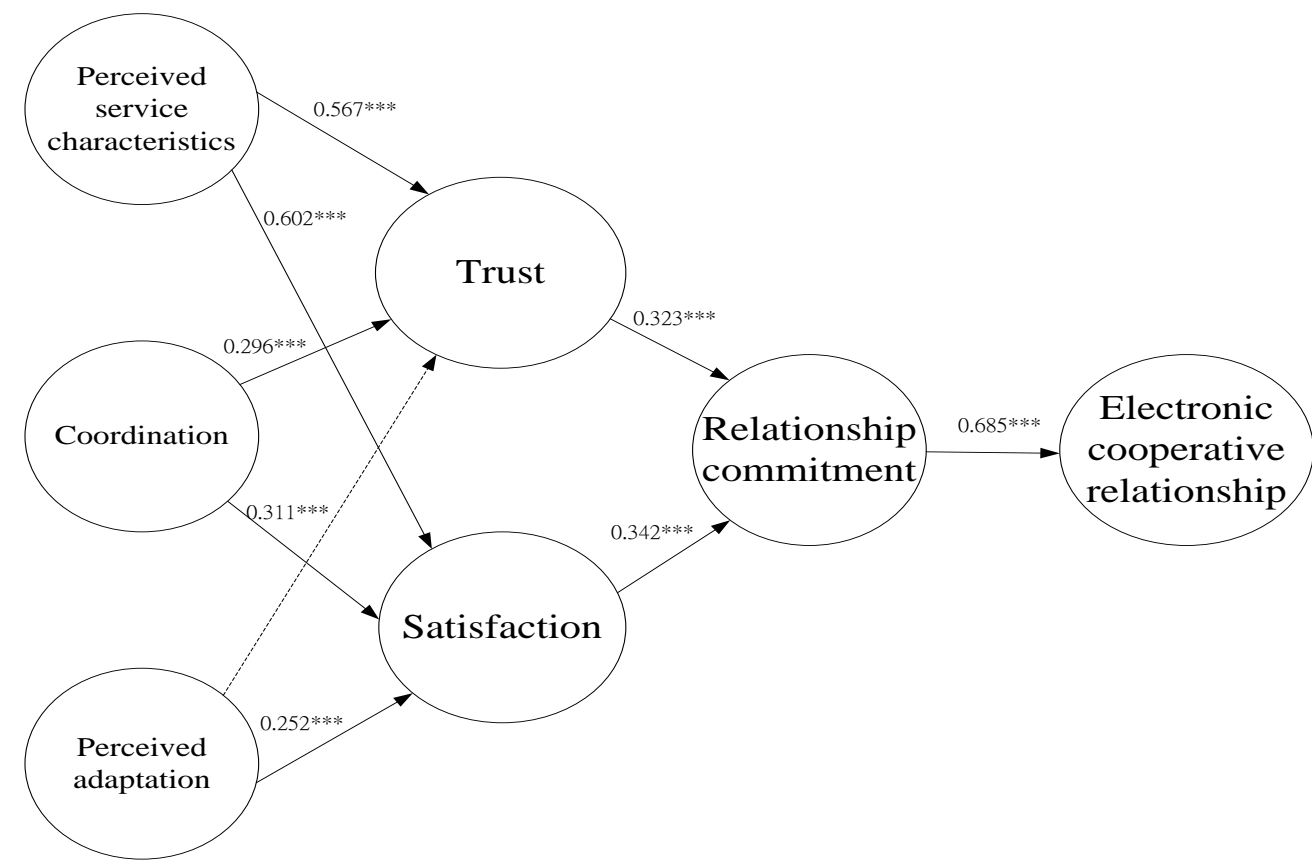

Note: Path coefficients are statistically significant $* * *$ denotes a significant value $\mathrm{p}<.01$

Figure 1. Testing results of the theoretical model

\subsection{Discussion}

The research results show that relationship commitment directly and positively influences increased electronic cooperative relationships ( $\mathrm{H} 1$ supported). This shows an increased relationship commitment by the retailers in elevating increased electronic cooperative relationship with the supplier. Both trust and satisfaction directly and positively influence relationship commitment ( $\mathrm{H} 2$ and $\mathrm{H} 3$ supported). This shows that 
strengthening the trust and satisfaction of retailers is helpful in strengthening relationship commitment.

This study also shows that perceived service characteristics directly influence trust and satisfaction ( $\mathrm{H} 4$ and $\mathrm{H} 5$ supported). This elevates the perceived service characteristics of the electronic exchange platform for retailers and helps promote their trust and satisfaction. An automobile supplier must strengthen the function of the electronic exchange platform and, more importantly, must obtain the service characteristics approval of the retailers. A supplier's Web site represents a communication platform through which retailers can find information about the supplier, its products and services, specifications, drawings, and brochures. Retailers can contact the supplier through the Web site, request suggestions or services, and provide feedback ${ }^{60}$. If the supplier wants to increase retailer flexibility by influencing the characteristics of anytime interaction, it does not affect other characteristics or consequences but may affect the perceived value of other retailers.

These results show that coordination directly influences trust and satisfaction (H6 and H7 supported). If an automobile supplier with an electronic exchange platform enjoys better coordination with retailers, trust and satisfaction are also higher. Business relationships develop because of reciprocal acts that parties coordinate based on not only the current state of a focal dyadic relationship but also their past experiences inside an extended network and their expectations of the future ${ }^{61}$. The requirements to which retailers must adapt are closely linked to the relationship they have with their suppliers. When a retailer adapts to these requirements, the relationship can evolve; as it evolves, the requirements change again. If the retailer does not adapt, then the relationship may stall or be halted. Because B2B e-commerce adaptation feeds back into the relationship, it increases cooperation.

The results of this study show that perceived adaptation directly influences satisfaction (H9 supported). If an automobile supplier elevates the perceived adaptation to use the electronic exchange platform, the degree of satisfaction is also higher. The link between electronic interactions and the buyer-seller relationship shows that influential suppliers may oblige their retailers to engage in and by explaining how these requirements evolve over time according to the interactive relationships.

The results of this study confirm that perceived adaptation does not directly and positively affect trust (H8 not supported). Because B2B e-commerce adaptation feeds back into the relationship, it increases cooperation. Substantial adaptation can be incremental over time. There is a link between adaptive behavior and the development stage of the 
relationship. From the perspective of the supplier, which is strongly influenced by its larger trading partners, electronic exchange platform adaptation can seem paradoxically discouraging. Suppliers that opt for rapid e-commerce dyadic adaptation or a client-oriented e-commerce adoption strategy benefit from certain tangible advantages such as increased revenues and are able to move quickly through the relationship levels. However, adaptation yields an increase in trust. This implies that interconnecting systems and processes (adaptation) does not provide risk-related value in addition to service and coordination.

\section{CONCLUSION AND SUGGESTIONS}

\subsection{Conclusion}

Because of the rapid developments of the Internet and the electronics business, many organizations integrate the procedures of their supply chains through information facilities required for coordinated business activities. The electronic exchange platform is viewed as an effective impetus for supply chain management activities. Automobile suppliers have recently made full use of electronic technologies and tools to integrate their supply chain information platforms. To increase the competitiveness of the supply chain, the electronic exchange platform proposed by an automobile supplier must include the coordination of retailers. Accurately and logically evaluating and measuring the automobile retailers' opinions of the electronic exchange platform as proposed by the automobile suppliers can help increase the cooperation of retailers. Therefore, this study attempts to construct and design scales suitable for measuring the increased electronic cooperative relationships and opinions of retailers with the supplier by strengthening relationship quality, from the perspectives of the retailers, based on the measurements and dimensions of previous literature and considering the characteristics of the electronic exchange platform of the automobile industry.

We investigated the effects of three dimensions of relationship quality (trust, relationship commitment, and satisfaction) along with perceived service characteristics, coordination, and perceived adaptation, on the increased electronic cooperative relationships between supplier and retailer. This study is based on the characteristics of the Taiwanese automobile industry and relevant theories from a review of the literature. The main contribution of this study is the integration of the means and concepts of relationship quality, forming an excellent model to explain the receptiveness and the increased electronic cooperative relationships between supplier and retailer. The high explanatory power of the results of the proposed model can help explain the increased electronic cooperative relationships between 
retailers and suppliers. For retailers, one of the main incentives to participate in the electronic exchange platform project is to strengthen the relationships with their suppliers. In addition, they would have more tools to manage widespread and multiple operations of their companies if they largely tailored their electronic exchange use.

This study shows that increased electronic cooperative relationships are positively affected by relationship commitment. In addition, relationship commitment is directly affected by trust and satisfaction. Trust is affected by perceived service characteristics and coordination. Satisfaction is affected by perceived service characteristics, coordination, and perceived adaptation. When automobile suppliers in the automobile industry add new capabilities and functions to the electronic exchange platforms in the future, they should first strengthen the trust, satisfaction, and relationship commitment of the retailers regarding the new platform. These steps can help forge cooperative relationships. Automobile suppliers must adequately exchange opinions with retailers regarding the goals and methods of the electronic exchange platform. Helping retailers understand that the platform operates with a win-win goal can effectively increase their relationship commitment. Because of the uniqueness of the electronic exchange platform, regardless of whether it is staff education and training, procedures, or adjustments to facilities, assistance of the automobile supplier is needed. The automobile supplier must increase the capabilities of the electronic exchange platform to help retailers increase sales techniques, to reduce risks, and to improve the forecast of market demand of automobiles and parts. Only then can electronic cooperative relationships be compatible with suppliers' long-term interests, increase their satisfaction, and raise their willingness to continue to invest in the electronic exchange platform. This in turn will help sustain electronic cooperative relationships.

\subsection{Suggestions}

This study investigates the effects of the organizational characteristics of supply chain partnerships on the sustainability of cooperative relationships. It also tests the effects of factors (unique to the automobile industry) on the sustainability of the electronic cooperative relationship. However, other factors might affect the sustainability of the electronic cooperative relationships in other industries. Therefore, future research should focus on industries with different characteristics, such as 3C retailers, clothing and accessories retailers, and convenience stores to compare differences in the results.

Casual relationships and dynamic changes are difficult to describe accurately using cross-sectional data. The questionnaire of this research focuses on current cooperative relationships and does not examine the stage 
of development in the supply chain partnership. However, alliance by itself is a dynamic interactive process. At different times and in different stages, the degree to which these factors are significant might vary significantly. Jap and Ganesan ${ }^{62}$ believe that during the initial exploration stage of the cooperation, investment by both parties helps develop commitment; during the final stage of the cooperation, drawing up contracts helps sustain more commitment. Therefore, during the different stages of the cooperative relationship, different mechanisms produce different benefits. Thus, suppliers might need to adopt various management styles.

The greater the number of factors affecting the sustainability of the electronic cooperative relationship, the more it helps to clarify the causal relationship. However, these factors might not have simple linear relationships. They might be additive, substitutes of one another, or produce interactive effects, despite enhancing communication and assisting in grasping information or achieving the alignment of goals. Therefore, these mechanisms might produce unique group patterns. In addition, relationship commitment can be classified as normative commitment, continuance commitment, and affective commitment to examine the respective effects on the increased electronic cooperative relationships between supplier and retailer. Relationship quality can also be elevated to relationship value in future research.

\section{REFERENCES}

[1] H. Boeck, Y. Bendavid, and E. Lefebvre, Evolving B2B e-commerce adaptation for SME suppliers. Journal of Business \& Industrial Marketing, 24009. http://dx.doi.org/10.1108/08858620910999439.

[2] K.K. Kim and N.S. Umanath, Information transfer in B2B procurement: An empirical analysis and measurement. Information \& Management, 42(6), p813-828, 2005. http://dx.doi.org/10.1016/j.im.2004.08.004.

[3] E.A. Williamson, D.K. Harrison, and M. Jordan, Information systems development with supply chain management. International Journal of Information Management, 24(5), p375-385, 2004. http://dx.doi.org/10.1016/j.ijinfomgt.2004.06.002.

[4] D. Davis, State of a new art: Manufacturers and trading partners learn as they go. Manufacturing Systems, 13(82), p2-10, 1995.

[5] J. Fulk and G. DeSanctis, Electronic communication for changing organisational Forms. Organisation Science, 6(4), p337-349, 1995. http://dx.doi.org/10.1287/orsc.6.4.337.

[6] R.E. Spekman, L.A Isabella, and T.C. MacAvoy, Alliance competence: Maximizing the value of your partnerships. Canada: John Wiley \& 
Sons. Inc., 2000.

[7] M. Grossman, The role of trust and collaboration in the Internet-enabled supply chain. The Journal of American Academy of Business, 5(1), p391-396, 2004.

[8] P. Finnegan, R. Galliers, and P. Powell, Systems planning in business-to-business electronic commerce environments. Information Technology and Management, 4(2), p183-198, 2003. http://dx.doi.org/10.1023/A:1022950328523.

[9] D.C. Chou, X. Yan, and D.C. Yen, Web technology and supply chain management. Information Management \& Computer Security, 12(4), p338-349, 2004. http://dx.doi.org/10.1108/09685220410553550.

[10] M. Morri, and C.R. Carter, Relationship marketing and supplier logistics performance: An extension of the key mediating variables model. Journal of Supply Chain Management, 41(4), p32-43, 2005. http://dx.doi.org/10.1111/j.1745-493X.2005.04104004.x.

[11] R.A. Lancioni, M.F. Smith, and H.J. Schau, Strategic Internet application trends in supply chain management. Industrial Marketing Management, $\quad 32(3), \quad$ p211-217, 2003. http://dx.doi.org/10.1016/S0019-8501(02)00264-X.

[12] W. Ulaga and A. Eggert, Relationship value and relationship quality: Broadening the nomological network of business-to-business relationships. European Journal of Marketing, 40(3/4), p311-327, 2006. http://dx.doi.org/10.1108/03090560610648075.

[13] P. Hadaya and L. Cassini, The role of joint collaboration planning actions in demand-driven supply chain. Industrial Management \& Data Systems, 107(7), p954-978, 2007. http://dx.doi.org/10.1108/02635570710816694.

[14] P. Hadaya and R. Pellerin, Determinants of construction companies' use of web-based interorganizational information systems. Supply Chain Management: An International Journal, 15(5), p371-384, 2010. http://dx.doi.org/10.1108/13598541011068305.

[15] J.K. Huntley, Conceptualization and measurement of relationship quality: linking relationship quality to actual sales and recommendation intention. Industrial Marketing Management, 35(6), p703-714, 2006. http://dx.doi.org/10.1016/j.indmarman.2005.05.011.

[16] R.C. Caceres and N.G. Paparoidamis, Service quality, relationship satisfaction, trust, commitment and business-to-business loyalty. European Journal of Marketing, 41(7/8), p836-866, 2007. http://dx.doi.org/10.1108/03090560710752429.

[17] K. Wulf, D. Odekerken-Schroder, and D. Iacobucci, Investments in consumer relationships: a cross-country and cross-industry exploration. Journal of Marketing, 65(4), p33-50, 2001. http://dx.doi.org/10.1509/jmkg.65.4.33.18386. 
[18] A. Walter, T. A. Muller, G. Helfert, and T. Ritter, Functions of industrial supplier relationships and their impact on relationship quality. Industrial Marketing Management, 32(2), p159-169, 2003. http://dx.doi.org/10.1016/S0019-8501(02)00230-4.

[19] P. Athanasopoulou, Relationship quality: A critical literature review and research agenda. European Journal of Marketing, 43(5/6), p583-610, 2009. http://dx.doi.org/10.1108/03090560910946945.

[20] Y. Liu, Y. Li, and L. Zhang, Control mechanisms across a buyer-supplier relationship quality matrix. Journal of Business Research, 63(1), p3-12, 2010. http://dx.doi.org/10.1016/j.jbusres.2009.01.005.

[21] F.R. Dwyer, P.H. Schurr, and S. Oh, Developing buyer-seller relationship. Journal of Marketing, 51(2), p11-27, 1987. http://dx.doi.org/10.2307/1251126.

[22] E.W. Anderson and B. Weitz, The use of pledge to build and sustain commitment in distribution channel. Journal of Marketing Research, 29(1), p18-34, 1992. http://dx.doi.org/10.2307/3172490.

[23] K.R. Moore, Trust and relationship commitment in logistics alliances: A buyer perspective. International Journal of Purchasing and Materials Management, 34(4), p24-37, 1998. http://dx.doi.org/10.1111/j.1745-493X.1998.tb00039.x.

[24] V.A. Zeithaml, L.L. Berry, and A. Parasuraman, The behavioral consequences of service quality. Journal of Marketing, 60(2), p31-46, 1996. http://dx.doi.org/10.2307/1251929.

[25] O. Ergun, J.L.H. Stamm, P. Keskinocak, and J.L. Swann, Waffle house restaurants hurricane response: A case study. International Journal of Production Economics, 126(1), p111-120, 2010. http://dx.doi.org/10.1016/j.ijpe.2009.08.018.

[26] R.M. Morgan and S. Hunt, The commitment-trust theory of relationship marketing. Journal of Marketing, 58(3), p20-38, 1994. http://dx.doi.org/10.2307/1252308.

[27] E.W. Anderson and M.W. Sullivan, The antecedents and consequences of customer satisfaction for firm. Marketing Science, 12(2), p125-143, 1993. http://dx.doi.org/10.1287/mksc.12.2.125.

[28] S. Ganesan, Determinants of long-term orientation in buyer-seller relationships. Journal of Marketing, 58(2), p1-19, 1994. http://dx.doi.org/10.2307/1252265.

[29] D.T. Wilson, An integrated model of buyer-supplier relationships. Journal of the Academy of Marketing Science, 23(4), p335-345, 1994. http://dx.doi.org/10.1177/009207039502300414

[30] L.C. Leonidou, D. Palihawadana, and M. Theodosiou, An integrated model of the behavioural dimensions of industrial buyer-seller relationships. European Journal of Marketing, 40(1/2), p145-172, 
2006. http://dx.doi.org/10.1108/03090560610637365.

[31] Foster, Creating digital value: At the heart of the I-E-I framework. Journal of Business \& Industrial Marketing, 20(4/5), p245-252, 2005. http://dx.doi.org/10.1108/08858620510603927.

[32] H.F. Mackenzie, Partnering Attractiveness in Buyer-Seller Relationships, Ph.D. Dissertation, University of Western Ontario, Landon Ontario, Canada, 1992.

[33] F. Selnes, An examination of effect of product performance on brand reputation, satisfaction and loyalty. European Journal of Marketing, 27(9), p19-35, 1993. http://dx.doi.org/10.1108/03090569310043179.

[34] J. Humphrey and H. Schmitz, Trust and inter-firm relations in developing and transition economies. The Journal of Development Studies, 34(4), p32-61, 1998. http://dx.doi.org/10.1080/00220389808422528.

[35] J. Rutter, From the sociology of trust towards a sociology of 'e-trust'. Working paper, ESRC Centre for Research on Innovation and Competition (CRIC), The University of Manchester, Manchester, 2000.

[36] S. Ba, Establishing online trust through a community responsibility system. Decision Support Systems, 31(3), p323-36, 2001. http://dx.doi.org/10.1016/S0167-9236(00)00144-5.

[37] G.L. Frazier, R.E. Spekman, and C.R. O'Neal, Just-in-time exchange relationships in industrial markets. Journal of Marketing, 52(4), p52-67, 1988. http://dx.doi.org/10.2307/1251633.

[38] J. Mohr, R.J. Fisher, and J.R. Nevin, Collaborative communication in interfirm relationships: Moderating effects of integration and control. Journal of Marketing, 60(3), p103-115, 1996. http://dx.doi.org/10.2307/1251844.

[39] J. Heikkila, From supply to demand chain management: efficiency and customer satisfaction. Journal of Operations Management, 20(6), p747-767, 2002. http://dx.doi.org/10.1016/S0272-6963(02)00038-4.

[40] S.J. Garcia-Dastugue and D. Lambert, Internet-enabled coordination in the supply chain. Industrial Marketing Management, 32(3), p251-263, 2003. http://dx.doi.org/10.1016/S0019-8501(02)00269-9.

[41] K.S. Soliman and B.D. Janz, An exploratory study to identify the critical factors affecting the decision to establish internet-based inter-organizational information systems. Information and Management, 41(6), p697-706, 2004. http://dx.doi.org/10.1016/j.im.2003.06.001.

[42] R.P. Vlosky, R. Fontenot, and L. Blalock, Extranets: Impacts on business practices and relationships. Journal of Business and Industrial Marketing, 15(6), p438-457, 2000. http://dx.doi.org/10.1108/08858620010349510.

[43] D. Hellstrom, The cost and process of implementation RFID 
technology to manage and control returnable transport items. International Journal of Logistics: Research and Application, 12(1), p1-21, 2009. http://dx.doi.org/10.1080/13675560802168526.

[44] H. Hakanson, International marketing and purchasing of industrial goods: An interaction approach. Chichester, England: Wiley, 1982.

[45] A.F. Salam, L. Iyer, P. Palvia, and R. Singh, Trust in e-commerce. Communication of the ACM, 48(2), p73-77, 2005. http://dx.doi.org/10.1145/1042091.1042093.

[46] S. Jones, M. Wilikens, P. Morris, and M. Masera, Trust requirements in e-business. Communications of the ACM, 43(12), p81-87, 2000. http://dx.doi.org/10.1145/355112.355128.

[47] B. Schneider and D.E. Bowen, Understanding customer delight and outrage. Sloan Management Review, 41(1), p35-46, 1999.

[48] Y.P. Yeh, Identification of factors affecting continuity of cooperative electronic supply chain relationships: Empirical case of the Taiwanese motor industry. Supply Chain Management - An International Journal, 10(4), p327- 335, 2005. http://dx.doi.org/10.1108/13598540510612802.

[49] T. Hennig-Thurau and A. Klee, The impact of customer satisfaction and relationship quality on customer retention: a critical reassessment and model development. Psychology and Marketing, 14(8), p737-764, 1997.

http://dx.doi.org/10.1002/(SICI)1520-6793(199712)14:8<737::AID-M AR2>3.3.CO;2-Z.

[50] R.L. Oliver, Satisfaction: A behavioral perspective on the customer, New York: McGraw-Hill, 1997.

[51] C. Gronroos, A service quality model and its marketing implication. European Journal of Marketing, 18(4), p36-44, 1984. http://dx.doi.org/10.1108/EUM0000000004784.

[52] K.A. Venetis, Service quality and customer loyalty in professional business service relationships: an empirical investigation into the customer-based concept in the Dutch advertising industry, Ph.D. Dissertation, Maastricht University, Maastricht, 1997.

[53] G.T. Gundlach, R.S. Achrol, and J.T. Mentzer, The structure of commitment in exchange. Journal of Marketing, 59(1), p78-92, 1995. http://dx.doi.org/10.2307/1252016.

[54] S. Qureshi and D. Vogel, Adaptiveness in virtual teams: organisational challenges and research directions. Group Decision \& Negotiation, 10(1), p27-46, 2001. http://dx.doi.org/10.1023/A:1008756811139.

[55] D. Lambert and T. Harrington, Measuring non-response bias in mail surveys. Journal of Business Logistics, 11(2), p5-25, 1990.

[56] J.T. Lessler and W.D. Kalsbeek, Non-sampling error in surveys. New York: Wiley, 1992. 
[57] L. Hatcher, A step-by-step approach to using the SAS system for factor analysis and structural equation modeling $\left(3^{\text {rd }}\right.$ ed.). USA: SAS Institute Inc., 1998.

[58] J.C. Anderson and D.W. Gerbing, Structural equation modeling in practice: A review and recommended two-step approach. Psychological Bulletin, 103(3), p411-423, 1988. http://dx.doi.org/10.1037//0033-2909.103.3.411.

[59] K.G. Joreskog and D. Sorbom, LISREL8: User's reference guide. Chicago, IL: Scientific Software International, 1993.

[60] N.G. Klanac, Types of linkages between service characteristics and customer consequences. European Journal of Marketing, 46(3/4), p313-330, 2012. http://dx.doi.org/10.1108/03090561211202495.

[61] S. Biggemann and F. Buttle, Coordinated interaction and paradox in business relationships. Journal of Business \& Industrial Marketing, 24(8), p549-560, 2009. http://dx.doi.org/10.1108/08858620910999420.

[62] S.D. Jap and S. Ganesan, Control mechanisms and the relationship life cycle: Implications for safeguarding specific investments and developing commitment. Journal of Marketing Research, 37(2), p227-245, 2000. http://dx.doi.org/10.1509/jmkr.37.2.227.18735. 
